\title{
Ethos, poética e política nos escritos de Luiz Gama
}

\author{
Profa. Dra. Ligia Fonseca Ferreira ${ }^{1}$
}

RESUMO: O objetivo deste artigo é analisar textos do poeta, advogado e abolicionista negro Luiz Gama, trazendo à tona dimensões subjetivas e estratégias enunciativas através das quais o autor se põe em cena e se revela como um sujeito de discurso no qual funda sua(s) identidade(s). Para tanto, recorremos ao conceito de ethos, segundo Dominique Maingueneau, articulado às indissociáveis condições sóciohistóricas de produção, circulação e recepção do discurso.

ABSTRACT: The purpose of this study is to analyse texts by the black poet, lawyer and abolitionist Luiz Gama, bringing to light subjective dimensions and enunciative strategies through which the author participates of the scene and reveals himself as the subject of the discourse in which he establishes his identity(ies). For that we turn to the concept of ethos, according to Dominique Maingueneau, joined to the inseparable socio-historical conditions of production, circulation and reception of the discourse.

Se de um quadrado

Fizer um ovo

Nisso dou provas

De escritor novo

(L. Gama, "Prótase") $)^{2}$

Consinta o imponente juiz (...) que eu lhe dê uma proveitosa lição de direito (...)

(L. Gama, "Foro da Capital")

Poeta, jornalista, advogado, Luiz Gonzaga Pinto da Gama (Salvador, 1830 - São Paulo, 1882) é um dos raros intelectuais negros brasileiros do século XIX, autodidata e o único a ter passado pela experiência da escravidão. Vive em cativeiro dos dez aos dezessete anos, quando começa a se alfabetizar. Pouco depois realiza uma façanha para a época, notável - ao conseguir reverter sua condição e provar ter nascido livre.

1 UNIFESP - Universidade Federal de São Paulo; e-mail: ligia.ff@uol.com.br

${ }^{2}$ Luiz Gama. "Prótase". In: Primeiras Trovas Burlescas e outros poemas. Organização, introdução e notas Ligia Fonseca Ferreira. São Paulo: Martins Fontes, 2000, p. 7-9; ver também Com a palavra Luiz Gama. Poemas, artigos, cartas, máximas. Organização, apresentação e notas Ligia Fonseca Ferreira. São Paulo: Imprensa Oficial, 2011, p. 47-48.

${ }^{3}$ Com a palavra Luiz Gama..., op. cit, p. 121. 
Conforme se depreende do relato feito pelo próprio Luiz Gama (FERREIRA, 2008, pp. 300-321), aparecem como fatos concomitantes e inter-relacionados a conquista da liberdade e a conquista do saber e da palavra que se encontraria no cerne de seu trabalho, tanto na esfera pública quanto na esfera privada, de sua missão, em suma, de sua própria identidade. O testemunho comovido do amigo Raul Pompéia, na homenagem póstuma ao abolicionista, é revelador :

"Toda [a sua] clientela miserável saía satisfeita, levando este uma consolação, aquele uma promessa, (...) [Ele] fazia tudo: libertava, consolava, dava conselhos, demandava, (...) exauria-se no próprio ardor, como uma candeia iluminando à custa da própria vida as trevas do desespero daquele povo de infelizes $(\ldots)^{p / 4}$.

Doze anos depois de começar a ler e a escrever, escapando do silêncio e da ignorância, Luiz Gama entrou para o mundo das letras com a publicação das Primeiras Trovas Burlescas $(1859,1861)$, mundo até então exclusivo de brancos. O autor de sátiras sociais e poemas românticos, o redator de periódicos políticos e popular conferencista, o combativo e paradigmático republicano ${ }^{5}$, o defensor dos escravos e do Direito daria provas de singular eloquência, tanto por meio da palavra falada quanto da palavra escrita, razão pela qual se distinguiria como exímio comunicador, com audiência sempre garantida e de ampla tessitura, dirigindo-se do escravo ao Imperador.

No entanto, as várias facetas deste homem plural foram de certa forma ofuscadas por uma história de vida que se teceu, perpetuando-se no tempo, numa intrincada construção polifônica. Entremeada de efeitos de realidade e de ficção, a nascente desta história pessoal encontra-se nos fatos narrados pelo próprio Luiz Gama na carta endereçada a seu jovem amigo Lúcio de Mendonça em 1880, na qual desvenda uma existência rocambolesca desde sua infância na Bahia e o trágico episódio de ter sido vendido como escravo aos dez anos de idade pelo próprio pai ${ }^{6}$. Ao discurso de Gama, então, viriam a se somar o de alguns biógrafos e ficcionistas (FERREIRA, 2008, p. 300321), ora louvando ora embaralhando seus feitos e verdadeiro papel, em narrativas em geral marcadas por apelos ideológicos diversos. Assim, Luiz Gama teve sua voz

4 Raul Pompéia, "Última página na vida de um grande homem", Gazeta de Notícias, 10/09/1882. In: Com a palavra Luiz Gama..., op. cit., p. 227-236.

5 Lúcio de Mendonça, "Luiz Gama” (ensaio biográfico). In: Com a palavra Luiz Gama..., op. cit., p. 263270.

6 “Carta a Lúcio de Mendonça, 25/07/1880”. In: Com a palavra Luiz Gama..., op. cit., pp. 199-203. 
empobrecida quando não silenciada. O poeta e escritor encontrou-se em posição de desequilíbrio frente à estática figura do lendário abolicionista, ficando em segundo plano o principal legado: seus textos poéticos, jornalísticos e epistolares.

Tivemos a grata oportunidade de editar na íntegra a poesia de Luiz Gama em Primeiras Trovas Burlescas \& outros poemas (2000), reunindo cinquenta e um poemas publicados em duas edições organizadas pelo próprio autor ainda em vida $(1859,1861)$ e, de forma avulsa, na imprensa paulistana até 1876. Lançado em 2011, Com a palavra Luiz Gama. Poemas, Artigos, Cartas, Máximas traz pela primeira vez, além de uma seleção de poemas extraídos da obra anterior, textos integrais, sendo vários deles inéditos, que ilustram a diversidade de sua produção, tanto do ponto de vista dos gêneros textuais quanto do leque temático. Tais escritos, marcados por uma insuspeitada complexidade, ao longo do tempo foram alvo de interpretações errôneas quando não deturpadas, anacrônicas, para não dizer francamente preconceituosas, que negaram a originalidade estética e envergadura intelectual de um autor que introduzira uma voz e um ponto de vista diferente (já que produzidos a partir de uma "diferença"), tanto sobre a sociedade brasileira quanto sobre si mesmo e seu próprio processo criativo (GAMA, 2000, pp. LXII-LXXI).

Assim, o objetivo deste artigo é analisar alguns textos de Luiz Gama trazendo à tona dimensões subjetivas e estratégias enunciativas, ou modalidades do "dizer", através das quais o autor se põe em cena e se revela, antes de mais nada, como um sujeito de discurso no qual funda sua(s) identidade(s) na poética e na política. Para tanto, recorremos particularmente ao conceito de ethos, definido por Dominique Maingueneau, que será brevemente apresentado aqui, em suas características formais sempre articuladas às indissociáveis condições sócio-históricas de produção, circulação e recepção do discurso.

\section{Sobre ethos e outros elementos do discurso}

De início, para nossa reflexão, é preciso ter em mente, conforme nos lembra Dominique Maingueneau (1993), que uma obra, "enquanto enunciado, implica também um contexto: uma narrativa, por exemplo, é assumida por um narrador inscrito num tempo e num espaço compartilhados com seu narratário [ou seja, o indivíduo ou público ou a quem tal narrativa se destina]” (p. 121; tradução nossa), sendo possível compreender a noção de contexto num sentido mais amplo (social, psicossocial, histórico, ideológico, político). Transpondo elementos da linguística para a análise 
literária, o mesmo autor afirma ainda que toda obra reproduz uma situação de enunciação formada por um "conjunto de coordenadas que balizam a enunciação: os protagonistas da interação linguageira, enunciador e co-enunciador (ou destinatário), bem como seu enraizamento espacial e temporal (Eu $\leftrightarrow$ Você, aqui, agora)" (MAINGUENEAU, 1993, p. 122). No entanto, não é suficiente dizer que a situação de enunciação seriam as circunstâncias de sua produção - por quem foi redigida, em que período, em que lugar, com que intencionalidade - já que cada gênero pressupõe "expectativas" específicas do público a que se destina e uma antecipação destas expectativas por parte do autor/enunciador no próprio discurso, bem como a verificação dos circuitos por que passam e as normas que presidem a sua recepção (IBID.). Ao mesmo tempo complementar e distinta dos elementos contextuais externos, os componentes da situação de enunciação descrita acima instauram uma "cenografia" que não é imposta por um tipo ou gênero de discurso, mas que constrói e se constrói através do próprio discurso, no próprio corpo de um texto. Assim, para interpretar um discurso, o analista, assim como o co-enunciador, deve ter condições de identificar os elementos que permitem reconhecer aquele como discurso político, religioso, jurídico, etc., além de definir os papéis dos seus protagonistas, o lugar e o tempo em que se produz, a intencionalidade subjacente. No entanto, tal processo nem sempre é evidente, criando armadilhas aos destinatários do discurso, quer se trate de um simples leitor de dada obra ou texto, ou até mesmo do próprio analista. Veja-se, por exemplo, esta "Carta a Ferreira de Menezes":

São Paulo, 13 de dezembro de 1880

Meu caro Menezes,

Estou em a nossa pitoresca choupana do Brás, sob ramas verdejantes de frondosas figueiras, vergadas sob o peso de vistosos frutos, cercado de flores olorosas, no mesmo lugar onde, no começo deste ano, como árabes felizes, passamos horas festivas, entre sorrisos inocentes, para desculpar ou esquecer humanas impurezas.

Daqui, a despeito das melhoras que experimento, ainda pouco saio à tarde, para não contrariar as prescrições do meu escrupuloso médico e excelente amigo, Dr. Jaime Serva.

Descanso dos labores e elucubrações da manhã, e preparo o espírito para as lutas do dia seguinte.

Este mundo é uma mitologia perfeita: o homem é o eterno Sísifo. (...)

Teu Luiz. 
Quando se lê o trecho acima, observa-se que há uma "cena" de imediato instaurada que nos permite dizer que se trata de uma carta (gênero epistolar), por suas características textuais e mesmo paratextuais (disposição tipográfica: cabeçalho, vocativo, saudações finais, assinatura); pode-se determinar a relação entre enunciador e o destinatário (um amigo, provavelmente, como se depreende pelo tom, forma de tratamento e finalização - "meu caro", "Teu Luiz" - as notícias sobre a família, saúde e atividades cotidianas), o perfil desse último (um indivíduo que compartilha dos mesmos saberes, enfim, uma relação entre iguais; identifica-se da mesma forma o tempo e espaço de onde brota o discurso ("São Paulo, 13 de dezembro de 1880") de uma correspondência privada, logo um escrito íntimo, no qual, entre amigos, se pode aludir a assuntos particulares com simplicidade e sinceridade, já que não será divulgada publicamente, e que procede de um personagem real e não fictício (não se trata, pois, do excerto de um romance epistolar). Vê-se ainda como o enunciador se põe fisicamente em cena, incluindo o seu destinatário na evocação sinestésica do local onde se dera o último encontro entre ambos ("ramas verdejantes de frondosas figueiras", "vistosos frutos", "flores olorosas"), como se desejasse, com isso, trazer seu destinatário para junto de si. Obtém-se, assim, um efeito de corporalidade do enunciador, resultante do fato que supõe já conhecido pelo amigo ("melhoras que experimento"), ao qual reforça, em tom filosófico, traços do caráter, como a benevolência comum a ambos (“desculpar e esquecer humanas impurezas") ou a qualidade de trabalhador incansável à imagem de uma figura mítica ("Descanso dos labores ... lutas do dia seguinte"; "o homem é o eterno Sísifo”).

A "cenografia" escolhida no trecho acima não corresponde à verdade do discurso do texto que foi deliberadamente manipulado no intuito de desencadear algumas hipóteses de sentido. Isto posto, a leitura do texto integral suscitaria outras interrogações, a saber :

- Em que medida se pode efetivamente considerar uma "carta" o texto publicado num jornal republicano de grande circulação - A Província de São Paulo - em 18 de dezembro de 1880? A que gênero discursivo pertence?

- A quem ou a que público, efetivamente, se destina? Que marcas enunciativas/discursivas atestam a presença do real ou reais destinatários?

- Como o enunciador atende ou rompe com as eventuais expectativas de seu(s) destinatário(s)? Que efeitos de sentido deseja provocar nesse(s)? 
- Que elementos nos remetem ao contexto e às condições de produção e circulação do texto?

- Que imagens o enunciador Luiz Gama produz de si?

- A partir desses dados, como definir uma "cenografia"?

Para avançar na análise e na interpretação dos textos dentro de uma lógica enunciativa, seria necessário apresentar, por fim, o funcionamento do ethos, conceito já presente na retórica antiga e reelaborado hoje no âmbito da análise de discurso. À luz do que se apresentou brevemente até aqui, como também da experiência social de cada indivíduo, não se negará que toda fala constrói uma imagem de seu enunciador, quer ele se refira ou não explicitamente a seu perfil, história ou qualidades. As estratégias discursivas ou a maneira como se enuncia, o estilo, as competências linguageiras, os saberes enciclopédicos, as crenças implícitas dão indícios de sua pessoa. Se por um lado o grau do sucesso na eficácia e na influência junto ao outro (o co-enunciador responsável igualmente pela produção do sentido na dinâmica da interação) pode às vezes ser medido, por outro lado depende em grande parte da legitimidade alcançada pelo enunciador. Para Aristóteles, o ethos cercava-se de questões morais focadas na pessoa do orador. Este deveria manifestar três qualidades em seu discurso: phronesis, ou sabedoria e competência; aretè ou honestidade, sinceridade ou virtude; e, por fim eunoia, a benevolência. Trata-se, portanto, da imagem que o orador constrói de si mesmo no tecido discursivo, independente da imagem prévia que dele possa ter seu auditório. Na retórica romana, contudo, enfatiza-se o estatuto social do orador, cuja autoridade provém de fatores externos à sua fala (origem social e familiar, função, reputação, etc.). Para Cícero, o homem deveria ser vir bonus dicendi peritus, ou seja, capaz de associar o caráter moral à capacidade de manejar o verbo. No entanto, a fim de agir sobre seu auditório, o orador não deve apenas empregar argumentos válidos (logos) e suscitar emoções (pathos); ele deve também afirmar sua autoridade e projetar uma imagem de si suscetível de inspirar confiança, aspecto que se encontra, pois, no âmago da interação, da intersubjetividade. Se, durante alguns séculos, pareceram declinantes os estudos sobre o ethos, em detrimento de outros fenômenos retóricos, modernamente o interesse pelas formas de construção de imagem de si através do discurso reemergiu nas teorias de Émile Benveniste, que atribui um papel central à enunciação dentro da análise linguística, até ganhar, definitivamente, um lugar de destaque na análise de discurso nos trabalhos de Ruth Amossy (1999) e de D. Maingueneau (2006). Da análise de grande variedade de discursos - político, jurídico, jornalístico, publicitário, literário -, um 
aspecto parece especialmente profícuo para a observação da construção da imagem de si (logo, de uma "identidade"), manifesta na "maneira de dizer" (escolhas linguísticas, estilísticas, do medium) em funcionamento nos textos de Luiz Gama (um ex-escravo que, em dado momento histórico, antes de "dizer" precisou assegurar-se dos meios para fazê-lo, bem como das condições para ser "ouvido" no ambiente intelectual de sua época). Trata-se do estatuto do locutor, de sua legitimidade, assentada em sua credibilidade e autoridade. Assim, o processo de legitimação pela fala aproxima-se da perspectiva sociológica dos campos, privilegiando uma imbricação entre "discurso e instituição" e não apenas fatores sociológicos externos (AMOSSY, 1999, p. 18).

Assim, à luz das breves considerações acima, procuraremos observar como Luiz Gama procede à construção do ethos em seus escritos poéticos e políticos, projetando, como num jogo de espelhos, mais do que a imagem de si, mas a própria imagem da sociedade do Brasil escravista na segunda metade do século XIX.

\section{2. "Se de um quadrado / fizer um ovo": Luiz Gama, escritor novo.}

Já nos primeiros versos de "Prótase", poema de abertura das Primeiras Trovas Burlescas de Getulino, o eu-lírico anuncia seu lugar e sua intenção de desmascarar um mundo torto à sua volta, orientando, de saída, não só a leitura como a expectativa de seus leitores:
No meu cantinho,
Encolhidinho,
Mansinho e quedo,
Banindo o medo,
Do torpe mundo,
Tão furibundo,
Em fria prosa
Fastidiosa -
O que estou vendo
Vou descrevendo.
Se de um quadrado
Fizer um ovo
Nisso dou provas
De escritor novo.

$$
\text { ("Prótase") })^{7}
$$

Pensando-se na lógica da legitimação do autor e da obra, podemos nos indagar : o que representou o aparecimento deste livro em torno dos anos 1860? Como um negro,

\footnotetext{
${ }^{7}$ Os poemas aqui citados encontram-se todos em Primeiras Trovas Burlescas \& outros poemas, op. cit., e em Com a palavra Luiz Gama..., op. cit.
} 
ex-escravo, desconhecido do público e na condição improvável de "escritor" conseguiu realizar tal publicação? Se ignorarmos essas perguntas iniciais, arriscamo-nos a enveredar por alguns vieses interpretativos. Com efeito, em meio à produção literária paulista e brasileira do século XIX, as Primeiras Trovas Burlescas (doravante PTB), único livro de Luiz Gama, iriam se destacar por vários aspectos inéditos. Contrariamente ao que declara o poeta, a novidade não provinha de sua capacidade em fazer mágicas com figuras geométricas. O enunciador, que, no caso, se cola à pele (negra) do autor, mostrava-se plenamente consciente da estranheza que haveria de causar. Enganaria a muitos, em sua época e mesmo em tempo mais próximo de nós, com seu falso retraimento e inocência, que um leitor atento não tardaria em identificar. Numa província de poucos leitores, raros escritores, um número ínfimo de tipografias e livrarias, o surgimento daquele autor sui generis deve ter despertado curiosidade. Ficase a imaginar quantos compreenderam tratar-se ali de um fato inédito. Clarividente, o autor antecipa a representação que poderiam fazer os leitores acerca de um poeta "inculto", que fugia aos moldes sociais e intelectuais dos letrados:

São rimas de tarelo, atropeladas, Sem metro, sem cadência e sem bitola Que formam no papel um ziguezague, Como os passos de rengo manquitola.

Grosseiras produções d'inculta mente, Em horas de pachorra construídas; Mas filhas de um bestunto que não rende Torpe lisonja às almas fementidas.

("Prótase")

Pela primeira vez, um negro, ex-escravo até doze anos antes analfabeto, cometia a audácia de denunciar as mazelas políticas, éticas e raciais da sociedade imperial. Dava à luz uma obra voltada essencialmente para a sátira política e social na qual assegura reiteradamente aos leitores - junto aos quais sabe ser necessário construir uma imagem de si e desconstruir prévias representações - que eles ouvirão ali um homem de firme caráter moral, que se atribui o papel de "fiscal" dos costumes:

E podem colocar-se à retaguarda

Os venerandos sábios de influência;

Que o trovista respeita submisso, Honra, pátria, virtude, inteligência. 
Só corta, com vontade nos malandros Que fazem da Nação seu Monte-Pio; No remisso empregado, sacripante No lorpa, no peralta e no vadio.

("Prótase")

Ao longo da obra, vê-se como a construção do ethos se acompanha da busca por legitimação do autor-enunciador, sem a qual perderia força tanto sua fala (discurso emanando de um enunciador "competente", "sincero/honesto" e "benevolente") quanto seu projeto (literário, político e a própria busca pelo reconhecimento na República das Letras). A partir de 1869, Luiz Gama se tornaria assíduo colaborador da imprensa, conquistando um lugar e uma visibilidade quase ostensiva na vida pública, ponto inicial de uma projeção que só faria aumentar. Alude-se aqui a um momento em que às palavras cabia produzir as imagens que, no mundo de hoje, frequentemente se substituem àquelas. Assim, há uma diferença significativa nas condições de produção das $P T B$, dada a sua excepcionalidade, em relação aos escritos posteriores, jornalísticos em sua maioria, uma vez que Luiz Gama não retornará à poesia. No entanto, o jornalista conserva uma qualidade escritural e estilística, além de uma relação estreita com a produção editorial, enquanto tipógrafo e dono de periódicos (GAMA, 2000, pp. XX) que justifica sua plena inscrição no campo literário. Recorde-se que, do século XIX a boa parte do século $\mathrm{XX}$, jornalismo e literatura mantêm vínculos estreitos. $\mathrm{O}$ jornalismo, que para muitos se desdobrava em ferramenta política, era realizado por escritores que, não raras vezes, iniciavam nessa atividade sua carreira literária, exercitando-as paralelamente. Assim, num Brasil escravocrata, há menos de quatro décadas independente e em pleno período romântico, durante o qual o negro-escravo desponta como tema na poesia ou personagem no romance, Luiz Gama finca uma voz inaugural, a do primeiro "autor" negro que se enuncia enquanto tal, figura até então ausente da literatura brasileira.

A escolha do pseudônimo - Getulino -, mesmo tendo Luiz Gama assinado a apresentação do livro com seu verdadeiro nome, não era fortuita e revelava, mais uma vez, que a cultura "em horas de pachorra construída", sem educação formal e em prazo curto não era, por essa razão, menos erudita. "Getulino" deriva de "Getúlia", território da África do Norte. Vê-se, pois, que Luiz Gama posiciona-se de cara como um autor de origem africana, sabendo que adentrava o círculo restrito dos letrados, privilégio exclusivo de brancos. Precocemente, no final dos anos $1850 \mathrm{fez}$ ecoar em seus versos 
uma ideologia, pautada nas teorias raciais pseudo-científicas cuja influência no Brasil em geral é situada a partir de 1870 (SCHWARCZ, 1993). Paradoxalmente, a própria enunciação de Luiz Gama o converte em contra-exemplo dos estigmas e preconceitos elaborados contra os negros:

\author{
Ciências e letras \\ Não são para ti[;] \\ Pretinho da Cost[a] \\ Não é gente aqui. \\ (...) \\ Desculpa, meu caro amigo, \\ Eu nada te posso dar; \\ Na terra que rege o branco, \\ Nos privam té de pensar!... \\ ("No álbum de meu amigo J. A. da Silva Sobral")
}

A afirmação ora explícita ora implícita de "negro sou" perpassa boa parte dos poemas, constituindo-se em locus enunciativo. Seu poema mais célebre, "Quem sou eu?", também conhecido por "Bodarrada" (GAMA, 2000, pp. 113-118) é com certa frequência citado de forma truncada, como se apenas interessassem os versos em que o enunciador escarnece da brancura ostentada por mestiços de toda espécie quando ascendem socialmente. Minimiza-se, assim, a relevância dos primeiros oitenta versos, nos quais o ethos moralista se reforça, dando mostras mais do que evidentes de que o autor-enunciador reforça seus valores, enumera seus alvos e dá uma dimensão quase autobiográfica, aludindo a dados pessoais e a seu momento histórico: "Vivo como ticotico"; "Tenho mui poucos amigos, / Porém bons, que são antigos"; "Faço versos, não sou vate"; / Que no século das luzes, / Os birbantes mais lapuzes, / Compram negros e comendas". Com as PTB, o poeta abandona o lugar prescrito para indivíduos de sua condição. No entanto, tal deslocamento, ou uma quase transgressão, se opera através do próprio discurso, permanentemente invocando e explicitando de forma provocativa a representação prévia do leitor co-enunciador ("Sei que é louco e que é pateta / Quem se mete a ser poeta”), pois só é possível se declarar não mais um mero observador, mas um intransigente avaliador ("Mas eu sempre vigiando/ Nessa súcia vou malhando"; "Dou de rijo no pedante"; "Não tolero o magistrado/ Que do brio descuidado, / Vende a lei, trai a justiça / - Faz a todos injustiça"), se revogada a cenografia inicial ("No meu cantinho/ Encolhidinho..."), na qual o falso retraimento significava , na verdade, a recusa de manter-se no lugar a que, socialmente, um negro e ex-escravo estava fadado a ocupar. Na sequência, em tom irreverente, o enunciador-autor dá de ombros ao que 
para muitos seria um insulto: "Se negro sou, ou sou bode / Pouco importa. O que isto pode?". Em vez de infamante, a palavra "negro" ou "bode", aplicada aos mestiços de pele mais escura, apenas retratava a realidade do país. Getulino afirma, assim, sua atrevida determinação de retirar as máscaras de indivíduos pertencentes às mais diversas camadas sociais ("Bodes há de toda casta, / Pois que a espécie é muito / Vasta...”), que se envergonham de suas origens. Esta temática retorna em outros poemas, a exemplo da seguinte estrofe de "Sortimento de gorras para a gente do grande tom":

Se os nobres desta terra empanturrados, Em Guiné têm parentes enterrados;

E, cedendo à prosápia, ou duros vícios, Esquecem os negrinhos seus patrícios; Se mulatos de cor esbranquiçada, Já se julgam de origem refinada, E, curvos à mania que os domina, Desprezam a vovó que é preta-mina: Não te espantes, ó Leitor, da novidade, Pois que tudo no Brasil é raridade!

(GAMA, 2000, p. 18)

Alude-se, pois, a um corpo social irrigado pelo sangue africano, semelhante ao próprio corpo de um enunciador implacável para com os "mulatos falsários" que renegam, desprezam e recalcam sua ascendência africana. Uma atitude contrária caracterizava Luiz Gama que, além de assumir-se negro, não dá as costas à solidariedade racial. Adaptando seu discurso à época e à realidade na qual sua arte se inscreve, o poeta se apresenta como um "Orfeu de carapinha" que substitui, sem cerimônia, os símbolos da poesia ocidental pelos equivalentes de origem africana, como se lê em "Lá vai verso":

Ó Musa de Guiné, cor de azeviche,

Estátua de granito denegrido,

Ante quem o Leão se põe rendido,

Despido do furor de atroz braveza;

Empresta-me o cabaço d'urucungo,

Ensina-me a brandir tua marimba,

Inspira-me a ciência da candimba,

Às vias me conduz d'alta grandeza.

(...)

Quero que o mundo me encarando veja,

Um retumbante Orfeu de carapinha,

Que a Lira desprezando, por mesquinha,

Ao som decanta de Marimba augusta;

E, qual outro Arion entre os Delfins, 
Os ávidos piratas embaindo -

As ferrenhas palhetas vai brandindo,

Com estilo que preza a Líbia adusta.

(GAMA, 2000, pp. 10-12)

Às alvas musas gregas, ele prefere a "Musa de Guiné, cor de azeviche" cujos poderes mágicos o farão penetrar no mundo invisível, ou melhor, não-visível aos olhos dos brancos ou dos mulatos insensíveis aos elementos e à linguagem próprios da cultura africana. Vemos, pois, que os deuses do Olimpo de pouco servem ao trovador que se entrega ao transe das danças e ritos africanos ("candimba", "caiumbas"); à insignificante lira, o vate negro prefere os ritmos animados dos tambores e berimbaus ("marimba", "zabumbas") para, ironicamente, cantar os "altos feitos", isto é, às desastrosas ações dos brancos ("gente luminosa"). Mas se o enunciador promete carnavalizar a tudo e a todos, o mesmo intuito se estende ao Orfeu ou ao "Africano fidalgote" por ele reinventado. Seu desejo é atrair a admiração e a adesão dos seus "patrícios" a fim de que também eles sejam protagonistas da festa, ingrediente indispensável da sua poética, como se pode ler na estrofe que encerra, compondo uma verdadeira cena teatral, o poema "Lá vai verso":

Nem eu próprio à festança escaparei;

Com foros de Africano fidalgote, Montado num Barão com ar de zote Ao rufo do tambor, e dos zabumbas, Ao som de mil aplausos retumbantes, Entre os netos da Ginga, meus parentes, Pulando de prazer e de contentes Nas danças entrarei d'altas caiumbas.

Luiz Gama jamais renuncia ao humor e à ironia para, através da linguagem poética, denunciar e combater as mazelas raciais, sociais e políticas do Brasil, o que constituía uma ousadia mais do que incômoda. A cidade na qual Luiz Gama viveu por mais de vinte anos da qual se tornou um dos mais "ilustres cidadãos" abrigava a Academia de Direito que ele jamais pôde cursar. Tanto ele como seus escritos circulam entre os letrados, em sua maioria formados naquela instituição. Apesar do fascínio que exerce sobre o futuro advogado das causas da liberdade ${ }^{8}$, o universo jurídico é por ele

\footnotetext{
8 Autodidata, sem jamais ter realizado estudos formais, Luiz Gama obtém autorização especial para advogar em primeira instância em 1869.
} 
duramente fustigado, transformando-se em tema recorrente em vários poemas, além de manter-se ainda tristemente atual:

Se a justiça, por ter olhos vendados,

É vendida, por certos Magistrados,

Que o pudor aferrando na gaveta,

Sustentam - que o Direito é pura peta;

E se os altos poderes sociais,

Toleram estas cenas imorais;

Se não mente o rifão, já mui sabido:

- Ladrão que muito furta é protegido -

É que o sábio, no Brasil, só quer lambança,

Onde possa empantufar a larga pança!

Trata-se aí de um dos temas privilegiados que, depois de receber tratamento jocoso nos versos satíricos, a partir de 1869 retornarão nos artigos jornalísticos de Luiz Gama sob outra configuração retórica, refletindo um status diferente e amadurecido. A essa altura, legitimado como membro da República das Letras e reconhecida figura pública cujas redes ultrapassam os limites da província paulista, Luiz Gama passa a se enunciar a partir de um outro locus enunciativo: a do sujeito que atua e intervém na polis como livre "cidadão". O jornalismo como ferramenta de propaganda e de disseminação do ideal republicano e abolicionista, a prática da advocacia principalmente voltada para a libertação de escravos, a crítica ao regime monárquico e ao "modo extravagante pelo qual se administra a justiça no Brasil"9 se tornam caminhos convergentes e formadores do "plano inclinado da política", espinha dorsal da consciência de Luiz Gama e de seu ser/estar no mundo.

\section{A construção do ethos nas "proveitosas lições de Direito"}

Depois de provar o sucesso e a legitimação propiciadas pela publicação de seu livro, Luiz Gama não abraçaria nenhum outro projeto literário e, em meados dos anos 1860, dá início a suas atividades na imprensa paulistana na qual viria a cumprir um papel histórico. Ao lado do desenhista italiano Ângelo Agostini, funda o Diabo Coxo (1864-1865), primeiro periódico ilustrado de São Paulo, e em 1866, cria o semanário Cabrião, com Agostini e Américo de Campos. Foi proprietário do semanário político e satírico O Polichinelo (1876) e colaborou em vários jornais da capital e da Corte.

\footnotetext{
9 Luiz Gama, "Foro da Capital”, 12/08/1869. In: Com a palavra...., op. cit., p. 115.
} 
Escrever se tornara um ato constante no cotidiano de Luiz Gama. Como amanuense da Secretaria de Polícia, cargo ocupado até o final dos anos 1860, familiarizou-se com a linguagem jurídica que deixaria marcas estilísticas em todos os seus textos. Instruindo-se na ciência jurídica e relacionando-se com os melhores advogados de São Paulo, constrói a erudição que o tornaria uma referência em todo o Império. Autodidata, referiu-se a si próprio em frase lapidar: "[Eu] não possuía pergaminhos, porque a inteligência repele diplomas, como Deus repele a escravidão" ${ }^{\text {. }}$. Dez anos depois da primeira edição das $P T B$, onde ele já havia deixado explícito seus sentimentos em relação aos (in)dignos representantes do poder judiciário, o advogado autodidata reafirma seu papel e suas intenções em um novo contexto. Ele se dirige claramente aos que o acusam de criticar os « doutores » por frustração ou despeito:

Impus-me espontaneamente a tarefa sobremodo árdua de tentar em juízo o direito dos desvalidos, e de, quando sejam eles prejudicados por uma inteligência das leis, ou por desassisado capricho das autoridades, recorrer à imprensa e expor, com toda a fidelidade, as questões e solicitar para elas o sisudo e desinteressado parecer das pessoas competentes.

Julgo necessária esta explicação para que alguns meus desafeiçoados, que os tenho gratuitos e rancorosos, deixem de propalar que costumo eu, como certos advogados, aliás considerados, clamar arrojadamente contra os magistrados por sugestões odientas, movido pelo malogro desastrado de pretensões desarrazoadas.

Fique-se, pois, sabendo, uma vez por todas, que o meu grande interesse[,] interesse inabalável que manterei sempre, a despeito das mais fortes contrariedades, é a sustentação plena, gratuitamente feita, dos direitos dos desvalidos que correrem ao meu tênue valimento intelectual. ${ }^{11}$

Luiz Gama não mede esforços para denunciar, pela imprensa, as prisões abusivas e as advertências que lhe encaminhavam os juízes prevaricadores e incompetentes. Tais situações convertiam-se em circunstâncias favoráveis para mostrar, de maneira aliás pouco modesta, seus conhecimentos e integridade. Constantemente relembra não possuir diplomas e, embora grave, o tom se pauta pela mesma ironia presente nas $P T B$ :

Não sou eu graduado em jurisprudência, e jamais frequentei academias. Ouso, porém, pensar que, para saber alguma coisa de

10 Luiz Gama, "Pela última vez", Correio Paulistano, 03/12/1869. In: Com a palavra..., op. cit., p. 136138.

11 Luiz Gama, "Foro da Capital”, Radical Paulistano, 29/07/1869. In: Com a palavra...., op. cit., p. 109113. 
direito não é preciso ser ou ter sido acadêmico. Além do que sou escrupuloso e não costumo intrometer-me de abelhudo em questões jurídicas, sem que haja feito prévio estudo de seus fundamentos. Do pouco que li relativamente a esta matéria, colijo que as enérgicas negações opostas às petições que apresentei, em meu nome e no próprio detido, são inteiramente contrárias aos princípios de legislação criminal e penal aceitos e pregados pelos mestres da ciência. ${ }^{12}$

Comparando-se estes escritos com os versos das $P T B$, observa-se, como a nova cenografia o exige, que Luiz Gama pode agora construir seu ethos reforçando tanto a phronesis, ou sabedoria e competência, como a aretè, ou sinceridade, componentes da retórica aristotélica e da arte da oratória que funda o discurso jurídico. Os mesmos argumentos que sustentam suas causas e interpretações da lei expõem tanto suas ligeiras feridas narcísicas quanto um certo sentimento de superioridade, acreditando na sua legitimidade obtida junto aos leitores que espera convencer da irrefutabilidade das provas apresentadas em seus artigos.

Luiz Gama inaugura a coluna "Foro da Capital" no Radical Paulistano, órgão do Partido Liberal Radical, em julho de 1869 e ali passaria a criticar e a dar lições de jurisprudência aos juízes paulistas, fazendo de seus artigos uma espécie de extensão de sua atividade como advogado dos desvalidos, homens e mulheres pobres, livres ou escravos, vítimas espoliadas por juízes cuja conduta era uma afronta ao próprio Direito (FERREIRA, 2010, pp. 219-244). Querer restabelecer a verdade e apontar os que atentam contra ela é menos grave do que tocar num tabu de mais de quarenta anos, a escravidão ilegal de africanos. Sob influência do conflito ainda em curso no Paraguai e que parecia anunciar o fim próximo da escravidão, Luiz Gama trouxe à tona um argumento jurídico inesperado na luta anti-escravista, desenterrando a lei de 7 de novembro de 1831 que declarava livres os escravos vindos do exterior do Império e previa penas severas para os importadores. No artigo anônimo intitulado "Escândalos" (30/09/1869), o autor finge chocar-se com a audácia dos abolicionistas que apontam "um fato altamente criminoso" tolerado pelas "indignas" autoridades do país, bem como as reações dos proprietários dos escravos preocupados com as conseqüências da efetiva aplicação da lei de 1831. O texto se encerra com a pergunta : "Deverão os amigos da humanidade, os defensores da moral cruzar os braços diante de tão abomináveis delitos

${ }^{12}$ Ibid. 
?"13. As características estilísticas do artigo "Escândalos" levam a crer que o texto é de autoria de Luiz Gama; além disso, ninguém melhor do que ele conhecia a situação dos africanos ilegalmente escravizados com o consentimento das autoridades de São Paulo. Dois meses depois, ele afirma publicamente estar tratando do caso de um escravo fugido de Amparo que o procurara confirmando ter entrado no Brasil em 1848. Munido de testemunhas, Luiz Gama solicita ao juiz, Dr. Rego Freitas, o depósito judicial na capital, recusado duas vezes pelo juiz que alegava não ter competência para aquela jurisdição. $O$ advogado e jornalista, que firmara o pacto com seus leitores de lhes comunicar o que se passa nos bastidores da justiça, servia-se, para a montagem da cena enunciativa, dos mais variados procedimentos enunciativos. Assim, como provas de verdade, reproduzia parcial ou integralmente suas petições e os despachos dos juízes, introduzindo em seus textos uma dimensão polifônica com destaque para sua própria voz. Sendo o Direito eminentemente uma questão de discurso, nas páginas dos jornais o público leitor tinha a possibilidade de acompanhar o trabalho, o raciocínio e as estratégias argumentativodicursivas de Luiz Gama. A ironia dos fatos explica a ironia do discurso que ganha relevo inclusive através do uso de recursos tipográficos, para dar conta da voz de outrem, traduzir a indignação do enunciador (letras em maiúsculas e em itálico) que estabelece um diálogo e elucida seu leitor (comentários entre colchetes), já que Luiz Gama se vê obrigado a dar uma "proveitosa lição de direito" ao jurisconsulto, desmoralizando-o publicamente sem pudor. Ao final, o ex-escravo não se privaria de lançar um desafio em tom estrondoso e colérico :

«N[aquele] requerimento ${ }^{14}$ todo firmado em lei, e sem período ou frase alguma que possa oferecer controvérsia, pôs o meritíssimo juiz este inqualificável despacho :

«- Constando da presente alegação [aliás denúncia, sapientíssimo senhor doutor] que o senhor do escravo Jacinto é morador no termo do Amparo, não estando, por isso, debaixo da jurisdição deste juízo, requeira ao juízo competente.

São Paulo, 25 de outubro de 1869.

Rego Freitas.»

E doze dias estudou o sábio jurisconsulto para lavrar este inconcebível despacho que faria injúria à inteligência mais humilde!

REQUEIRA AO JUÍZO COMPETENTE?!...

${ }^{13}$ Ibid., p. 117.

${ }^{14}$ Trata-se de documento anteriormente encaminhado por Luiz Gama. 
Consinta o imponente juiz, sem ofensa do seu amor próprio, que muito respeito, e da reconhecida ilustração de seus venerandos mestres, que eu lhe dê uma proveitosa lição de direito, para que não continue a enxovalhar em público o pergaminho de bacharel que foi-lhe conferido pela mais distinta das faculdades jurídicas do Império.

Esta lição está contida e escrita com a maior clareza na seguinte disposição de Lei, que o meritíssimo juiz parece ou finge ignorar :

«Em qualquer tempo, em que o preto requerer a QUALQUER JUIZ DE PAZ, OU CRIMINAL, que veio para o Brasil depois da extinção do tráfico, o juiz o interrogará sobre todas as circunstâncias que possam esclarecer $\mathrm{o}$ fato, $\mathrm{e}$ OFICIALMENTE PROCEDERÁ A TODAS AS DILIGÊNCIAS NECESSÁRIAS PARA CERTIFICAR-SE DELE, obrigando o senhor a desfazer as dúvidas que suscitarem-se a tal respeito.

HAVENDO PRESUNÇÕES VEEMENTES DE SER O PRETO LIVRE, O MANDARÁ DEPOSITAR e proceder nos mais termos da Lei.»

Nessa disposição é que devera o sr. dr. Rego Freitas estribar o seu despacho, como juiz [íntegro], e não em sofismas fúteis que bem revelam a intenção de frustrar o direito de um miserável africano, que não possui brasões nem títulos honoríficos para despertar a simpatia e a veia jurídica do eminente e amestrado jurisconsulto.

Descanse, porém, o sr. dr. Rego Freitas, porque eu protesto perante o país inteiro de obrigá-lo a cingir-se à lei, respeitar o direito e cumprir estritamente o seu dever para o que é pago com o suor do povo, que é o ouro da Nação. (...)

\section{Luiz Gama.» 15}

O advogado insolente foi logo repreendido com uma estrepitosa demissão do seu cargo de amanuense numa repartição pública. Ele mesmo orquestrara a teatralidade de um fato que, na interpretação política dos companheiros da imprensa liberal e antimonarquista de São Paulo, revelava dimensões mais profundas do que a simples punição de um indivíduo e retomava o espetáculo da História que atravessava a estrutura mental do país havia pouco sacudido pela maré conservadora que culminou com a queda do gabinete liberal de Zacarias de Góes e Vasconcelos (FERREIRA, 2010, pp. 236-237). Um dos efeitos de sua demissão que por mais de quinze dias ocupou quase cotidianamente os jornais foi a ruptura de Luiz Gama com seu "amigo e protetor", Conselheiro Furtado de Mendonça, a quem dedicara as PTB. "Os protetores são os

${ }^{15}$ Luiz Gama, "Foro da Capital”, Radical Paulistano, 13/11/1869. In: Com a palavra...., op. cit., p. 121. 
piores tiranos », registrou, desiludido, o mulato Lima Barreto em seu Diário Íntimo. O autor do Triste Fim de Policarpo Quaresma compreendera, pouco tempo depois da proclamação da República, que a proteção pressupunha autoritarismo e submissão. No século anterior, ao romper com Furtado de Mendonça, Luiz Gama matava simbolicamente o pai e rompia não só os laços pessoais. Doravante, o ex-escravo e negro letrado que se reconstruiu social e "discursivamente", alçando-se ao que considerava ser a plena condição de "cidadão", tomaria publicamente a palavra para afirmar a autonomia de seus atos e de suas opiniões. Em certo sentido, ele não só conquista, novamente, a sua liberdade frente ao homem que o introduzira no mundo das letras e do direito, mas também perante um perverso sistema no qual o paternalismo regia as relações entre brancos e negros, mantendo estes, fossem livres ou libertos, em posição subalterna. A crise entre os dois homens representa, de alguma forma, o confronto, em vários níveis, entre um branco e um negro, o senhor e o escravo, o mestre e o discípulo, o conservador e o liberal, o escravagismo e o abolicionismo. O forte sentimento de honra em Luiz Gama o faz repelir a acusação de ser "ingrato". Princípios e valores não podem ser sacrificados em nome da amizade, especialmente quando esta supõe subordinação. O ex-escravo, agora homem de influência e de influente palavra, presta uma última homenagem àquele que transformara o obscuro discípulo em cidadão virtuoso. A despedida tomou ares de manifesto abolicionista e republicano num texto curiosamente escrito em terceira pessoa, desdobramento enunciativo frequente nas escritas do eu. Assim, ao enunciar-se desta forma, Luiz Gama produz um efeito de distanciamento em relação àquele outro-ele mesmo, apreciado desde um ponto de vista exterior, fazendo-se espectador da cena enunciativa por ele construída. Sob seus olhos desenrolava-se sua excepcional história, provocando não tanto a admiração mas, antes, quase um assombro ao rememorar os desafios por ele protagonizados e heroicamente vencidos. Como em outras oportunidades, Luiz Gama, agora com maior veemência atribui-se uma missão política, inscrevendo publicamente seu destino num destino coletivo:

O ex-soldado hoje, tão honesto como pobre, quaker ou taciturno ebionita, arvorou à porta da sua cabana humilde o estandarte da emancipação, e declarou guerra de morte aos salteadores da liberdade.

Tem por si a pobreza virtuosa, combate contra a imoralidade e o poder.

Os homens bons do país, compadecidos dele, chamamno de louco ; os infelizes amam-no ; o governo persegue-o. 
Surgiu-lhe na mente inapagável um sonho sublime, que o preocupa : o Brasil americano e as terras do Cruzeiro, sem reis e sem escravos!

Eis o estado a que chegou o discípulo obscuro do exmo. sr. conselheiro Furtado de Mendonça.

Enquanto os sábios e os aristocratas zombam prazenteiros das misérias do povo ; enquanto os ricos banqueiros capitalizam o sangue e o suor do escravo ; enquanto os sacerdotes do Cristo santificam o roubo em nome do Calvário ; enquanto a venalidade togada mercadeja impune sobre as aras da justiça, este filho dileto da desgraça escreve o magnífico poema da agonia imperial. Aguarda o dia solene da regeneração nacional, que há de vir ; e, se já não viver o velho mestre, espera depô-lo com os louros da liberdade sobre o túmulo, que encerrar as suas cinzas, como testemunho de eterna gratidão ${ }^{16}$.

A série de artigos publicados no Correio Paulistano de 20 de novembro a 3 de dezembro de 1869 possui notável eficácia discursiva. Paralelamente às narrativas e comentários sobre fatos judiciários e políticos, dos diferentes textos, marcados por aspectos micro-biográficos e pela presença ostensiva do autor na cena enunciativa, aos poucos surge um Luiz Gama arauto e símbolo. Lutando para limpar-se das acusações recebidas e obter reparação, é não só sua imagem, mas a própria justiça que sai reabilitada.

Conforme se pretendeu demonstrar nesse trabalho, além de servir de estímulo para a descoberta ou redescoberta de Luiz Gama, o conceito de ethos permite abordar, sob novas perspectivas, seus escritos poéticos e políticos. Assim, graças à força persuasiva e à legitimidade sustentada pelos fatos mas sobretudo alcançada pelo sujeito de discurso em que Luiz Gama exemplarmente funda sua(s) identidade(s), saímos do plano da questão individual, do acontecimento puro e simples, e somos levados ao campo, mais amplo e universal, do Humano e da História...

\section{Referências bibliográficas}

AMOSSY, Ruth. Images de soi dans le discours. La construction de l'ethos. Lausanne, Paris: Delachaux \& Niestlé S.A., 1999.

Imagens de si no discurso: a construção do ethos. São Paulo:

Contexto, 2005.

\footnotetext{
${ }^{16}$ Luiz Gama, "Pela última vez", Correio Paulistano, 3/12/1869. In: Com a palavra Luiz Gama...., op. cit., p. 136-138.
} 
Com a palavra Luiz Gama. Poemas, artigos, cartas, máximas. Organização, apresentação e notas Ligia Fonseca Ferreira. São Paulo: Imprensa Oficial, 2011.

FERREIRA, Ligia Fonseca. Luiz Gama por Luiz Gama: carta a Lúcio de Mendonça. In: Teresa. Revista de Literatura Brasileira da USP. São Paulo: 8-9: 300-321, 2008.

Luiz Gama: defensor dos escravos e do Direito. In: Os Juristas na formação do Estado-Nação brasileiro (1850-1930). Carlos Guilherme Mota; Gabriela Nunes Ferreira (coord.). São Paulo: Saraiva, 2010, pp. 219-244.

GAMA, Luiz. Primeiras Trovas Burlescas e outros poemas. Organização, introdução e notas Ligia Fonseca Ferreira. São Paulo: Martins Fontes, 2000.

MAINGUENEAU, Dominique. Le contexte de l'oeuvre littéraire. Paris: Dunod, 1993. Cenas da Enunciação. Organizado por Sírio Possenti e Maria Cecília Pérez de Souza-e-Silva. Curitiba: Criar Edições, 2006.

SCHWARCZ, Lilia. O espetáculo das raças. Cientistas, instituições e questão racial no Brasil (1870-1930). São Paulo: Companhia das Letras, 1993. 